\title{
Sistem Penyewaan Lapangan Futsal Berbasis Mobile Android
}

\author{
Fatoni*1 $^{1}$, Heri Susanto ${ }^{2}$ \\ ${ }^{1,2}$ Program Studi Teknik Informatika, Fakultas Ilmu Komputer, Universitas Bina Darma \\ ${ }^{1,2}$ Jln. Jend A. Yani No. 3 Palembang 30264 \\ *1.
}

\begin{abstract}
Abstrak-- Futsal merupakan salah satu olahraga yang populer di Indonesia. Selain lapangan yang bagus, sistem penyewaan lapangan yang baik juga menjadi faktor pertimbangan bagi penyewa memilih tempat penyewaan lapangan futsal. Sistem penyewaan dan pendataan pada DoR Futsal Baturaja yang masih manual akan membuat lamanya proses pencatatan dan pencarian informasi yang diminta guna mengambil suatu keputusan, serta sistem pemesanan yang harus tatap muka dan datang langsung ke tempat tertentu akan memakan banyak waktu untuk melakukanya. Saat ini ponsel telah menjadi bagian penting dalam kehidupan sehari-hari. Android merupakan sistem operasi yang paling banyak digunakan oleh pecinta smartphone saat ini. Oleh sebab itu dibutuhkan suatu sistem penyewaan lapangan futsal berbasis mobile. Dengan begitu calon penyewa dapat mengecek jadwal melalui android, serta dapat langsung melakukan pemesanan lapangan melalui aplikasi mobile android sehingga proses penyewaan lapangan futsal dapat dilakukan lebih efektif dan efisien.
\end{abstract}

Kata Kunci-Sistem, Penyewaan, Jadwal, Futsal, Mobile, Android.

\section{Pendahuluan}

Organisasi semakin khawatir tentang kinerja lingkungan dari operasi mereka dalam lingkungan yang kompetitif saat ini. Hal ini karena secara efektif meningkatkan kinerja organisasi dapat membantu organisasi untuk memenuhi peraturan dan standar kepatuhan, meningkatkan profitabilitas organisasi, memberikan organisasi dengan peluang bisnis, dan meningkatkan posisi kompetitif organisasi di pasar, akibatnya organisasi telah menerapkan kebijakan dan strategi khusus untuk meningkatkan kinerja organisasi.

Perkembangan teknologi informasi memungkinkan berbagai kegiatan dapat dilaksanakan dengan baik. Teknologi informasi adalah suatu teknologi yang digunakan untuk mengolah data, termasuk memproses, mendapatkan, menyusun, menyimpan, memanipulasi data dalam berbagai cara untuk menghasilkan informasi yang berkualitas, yaitu informasi yang relevan, akurat, dan tepat waktu. Digunakan untuk keperluan pribadi, bisnis, pemerintahan maupun swasta dalam pengambilan keputusan.

Di dalam sebuah perusahaan atau bidang bisnis baik kecil, menengah, maupun berskala besar, biasanya perlu menggunakan sebuah sistem informasi yang menunjang kegiatan perusahaan maupun usaha bisnis tersebut. Dengan adanya sistem informasi tersebut maka segala sesuatu kegiatan dapat terkontrol satu sama lain dengan baik.

Sistem pemesanan atau penyewaan pada umumnya digunakan oleh perusahaan untuk memberikan pelayanan pada penggunanya, dimana dalam proses penyewaan akan mempercepat proses pesanan pelanggan. Hal ini akan mengefisiensikan waktu yang digunakan untuk melayani pelanggan yang datang secara langsung. Salah satu contoh yang telah menerapkan sistem pemesanan atau penyewaan berbasis mobile android adalah Pemesanan Tiket Bus Pada PO Sinar Dempo Berbasis Android [2] dan Aplikasi Ponsel Berbasis Android Untuk Penjualan Pada Kios Eceran Q-Mono Flower [4] dimana dalam sistem tersebut menyediakan fiturfitur yang dapat mempermudahkan pelayan dalam pencatatan transaksi pemesanan.

Android adalah sistem operasi untuk telepon seluler yang berbasis Linux, Android menyediakan platform terbuka bagi para pengembang untuk menciptakan aplikasi mereka sendiri untuk digunakan oleh bermacam peranti bergerak. [1].

Saat ini ponsel telah menjadi bagian penting dalam kehidupan sehari-hari. Interaksi manusia modern dengan ponsel, tablet, atau perangkat bergerak lainnya, mungkin sudah lebih intensif dibandingkan interaksi dengan laptop atau desktop. Dengan demikian aplikasi pada perangkat bergerak cenderung akan lebih sering digunakan karena tingkat intensitas pemakaiannya yang lebih tinggi dibandingkan dengan laptop atau desktop.

Futsal saat ini merupakan salah satu olahraga yang paling diminati diIndonesia, semua kalangan dari berbagai umur pun gemar dengan olahraga futsal. Banyaknya penggemar olahraga futsal ini sehingga menjadikan peluang bisnis yang sangat menjanjikan. Tidak mengherankan apabila saat ini banyak dijumpai tempat penyewaan lapangan futsal dimana-mana.

DoR Futsal Baturaja adalah sebuah usaha yang bergerak dibisnis penyewaan lapangan futsal. Pada DoR Futsal Baturaja sistem penyewaan lapangan futsal masih dilakukan secara manual dengan cara mencatat setiap penyewa, calon penyewa serta members dan non members dalam satu buku sehingga menyulitkan bagian pendataan penyewa untuk menyalin data 
para members setiap minggunya sesuai dengan hari dan jam yang dipesan oleh members dan non members.

Oleh sebab itu dibutuhkan suatu sistem informasi penyewaan lapangan futsal yang terkomputerisasi dan berbasis mobile android. Dengan begitu calon penyewa dapat mengecek jadwal melalui perangkat imobile androidi mereka dan baru memesan apabila jadwal yang diinginkan benar-benar kosong. Hal ini juga memudahkan pihak DoR Futsal dalam pencarian informasi jadwal bagi para calon penyewa yang masih menelepon atau datang langsung guna menanyakan informasi jadwal penyewaan lapangan futsal. Informasi yang didapat akan lebih cepat, tepat dan juga akurat, dengan begitu akan membuat sistem penyewaan lapangan futsal akan lebih efektif dan efisien.

Masalah yang akan dibahas dalam penelitian ini adalah Bagaimana Sistem Penyewaan Lapangan Futsal Berbasis Mobile Android pada DoR Futsal Baturaja ?. Sedangkan tujuan penelitian ini membangun sistem penyewaan lapangan futsal berbasis mobile android guna memudahkan pihak DoR Futsal dalam melakukan pengolahan data dengan cepat sehingga menghasilkan informasi yang berkualitas, serta membuat calon penyewa mengetahui jadwal tanpa harus datang atau menghubungi pihak DoR Futsal.

Adapun manfaat yang akan dicapai dari hasil penelitian ini adalah :

1. Dengan adanya sistem penyewaan lapangan futsal berbasis mobile android ini diharapkan memberi kemudahan pihak DoR Futsal dalam pencatatan data penyewa (members dan non members), serta kemudahan dalam pencarian informasi mengenai penyewaan lapangan futsal yang dibutuhkan oleh calon penyewa lapangan tersebut.

2. Di harapkan dengan adanya sistem penyewaan ini membuat para calon penyewa tidak harus menunggu terlalu lama dalam mendapatkan informasi mengenai penyewaan lapangan futsal di DoR Futsal, serta memudahkan penyewa dalam hal pemesanan lapangan. Penyewa dapat melakukan pemesanan lapangan melalui aplikasi mobile berbasis android.

\section{METODE PENELITIAN}

\section{A. Metode Penelitian}

Metode penelitian yang digunakan dalam penelitian ini adalah Metode Deskriptif. Metode deskriptif atau metode survey adalah suatu metode dalam meneliti sekelompok manusia, suatu objek, suatu set kondisi, suatu sistem pemikiran, ataupun suatu peristiwa pada masa sekarang. Tujuan penelitian deskriptif ini adalah untuk membuat deskripsi, gambaran, atau lukisan secara sistematis, factual dan akurat mengenai fakta-fakta, sifat-sifat serta hubungan antar fenemona yang diselidiki. Ditinjau dari jenis masalah yang diselidiki, teknik dan alat yang digunakan, serta tempat dan waktu penelitian dilakukan.

\section{B. Metode Pengumpulan Data}

Metode pengumpulan data yang dipakai dalam penelitian ini meliputi.

\section{1) Metode Observasi}

Pada metode ini kegiatan yang dilakukan adalah melihat serta mempelajari permasalahan sistem pengolahan data penyewaan lapangan futsal pada DoR Futsal Baturaja yang akan diteliti.

\section{2) Metode Studi Pustaka}

Studi pustaka, mempelajari, mencari, dan mengumpulkan data yang berhubungan dengan penelitian seperti buku dan internet yang berkaitan dengan objek permasalahan.

\section{3) Wawancara}

Peneliti mengadakan tanya jawab langsung dengan pimpinan DoR Futsal guna mendapatkan informasi yang berkaitan dengan penelitian yang dilakukan, serta pada penyewa dan staf lain yang berhubungan dengan penelitian.

\section{Metode Pengembangan Sistem}

Metode pengembangan sistem adalah menyusun suatu sistem yang baru untuk menggantikan sistem yang lama secara keseluruhan atau memperbaiki sistem yang telah berjalan. Dalam penelitian ini menggunakan metode pengembangan sistem sekuensiel linier. Metode sekuensiel linier Roger S. Pressman, Ph.D. [3] terdapat 6 (enam) tahapan untuk dapat mengembangkan suatu perangkat lunak, yaitu :

1) Rekayasa dan pemodelan sistem atau informasi

Membangun syarat dari semua elemen sistem dan mengalokasikan beberapa subset dari kebutuhan ke perangkat lunak tersebut.

\section{2) Analisis kebutuhan perangkat lunak}

Proses pengumpulan kebutuhan diintensifkan dan difokuskan, khususnya pada perangkat lunak. Untuk memahami sifat program yang dibangun, perekayasa perangkat lunak (analis) harus memahami domain informasi, tingkah laku, unjuk kerja dan antarmuka (interface) yang diperlukan.

\section{3) Desain}

Proses desain menerjemahkan syarat atau kebutuhan ke dalam sebuah representasi perangkat lunak yang dapat diperkirakan demi kualitas sebelum dimulai pengkodean.

\section{4) Generasi kode}

Desain harus diterjemahkan ke dalam bentuk yang dapat dimengerti oleh mesin, yaitu ke dalam bahasa pemrograman melalui proses coding.

\section{5) Pengujian}

Proses pengujian berfokus pada logika internal perangkat lunak, memastikan bahwa semua pernyataan sudah diuji, dan pada eksternal fungsional yaitu mengarahkan pengujian untuk menemukan kesalahankesalahan dan memastikan bahwa input yang dibatasi akan memberikan hasil aktual yang sesuai dengan hasil yang dibutuhkan.

\section{6) Pemeliharaan}

Pemeliharaan perangkat lunak mengaplikasikan lagi setiap fase program sebelumnya dan tidak membuat yang baru lagi. 


\section{Analisis dan Perancangan}

DoR Futsal begerak dibisnis penyewaan lapangan futsal, pada DoR Futsal Baturaja sistem penyewaan lapangan futsal juga masih dilakukan secara manual dengan cara mencatat setiap penyewa, calon penyewa serta members dalam satu buku yang tentunya menyulitkan bagian pendataan penyewa untuk menyalin data members setiap minggunya sesuai dengan hari dan jam yang dipesan oleh members. Selain itu dalam menyampaikan informasi kepada calon penyewa yang ingin mengetahui hari dan jam lapangan yang kosong, pihak DoR Futsal harus mengecek data satu persatu dan menyamakan data members dengan minggu sebelumnya untuk menghindari penumpukan jadwal. Selama ini proses pemesanan pada DoR Futsal yaitu calon penyewa dapat mengirim SMS (short mesages services), telepon atau datang langsung ke tempat dan menanyakan informasi jadwal tersebut untuk selanjutnya baru mendapat informasi jadwal yang kosong. Ketika melakukan pemesanan penyewa juga harus mendatangi tempat penyewaan guna registrasi pembayaran maupun menyerahkan uang muka, kemudian menunggu petugas memeriksa buku pemesanan yang berisi data penyewa dan jadwal lapangan kosong yang masih tersedia. Hal ini tentu saja tidak praktis. Penyewa akan menghabiskan banyak waktu untuk mendatangi DoR Futsal, menunggu petugas mencatat pemesanan, dan memeriksa data pemesanan.

Sistem penyewaan yang lama ini perlu dikembangkan guna mendapatkan sistem baru yang diharapkan dapat membuat proses penyewaan lapangan futsal yang lebih efektif dan efisien.

\section{E. Desain Sistem}

Tahapan dimana mengubah kebutuhan yang masih berupa konsep menjadi konsep rancangan sistem yang baik, karena dengan adanya rancangan pembuatan sistem akan lebih terarah dan mudah dikembangkan. Menjabarkan proses yang telah direncanakan, tahapan dimana spesifikasikan proyek secara lengkap dibuat. Desain sistem harus terstruktur dan sesuai dengan perencanaan yang telah ditentukan. Perancangan yang kurang baik akan mengakibatkan pembuatan sistem kurang maksimal dan tidak tepat waktu.

\section{1) Use Case Diagram}

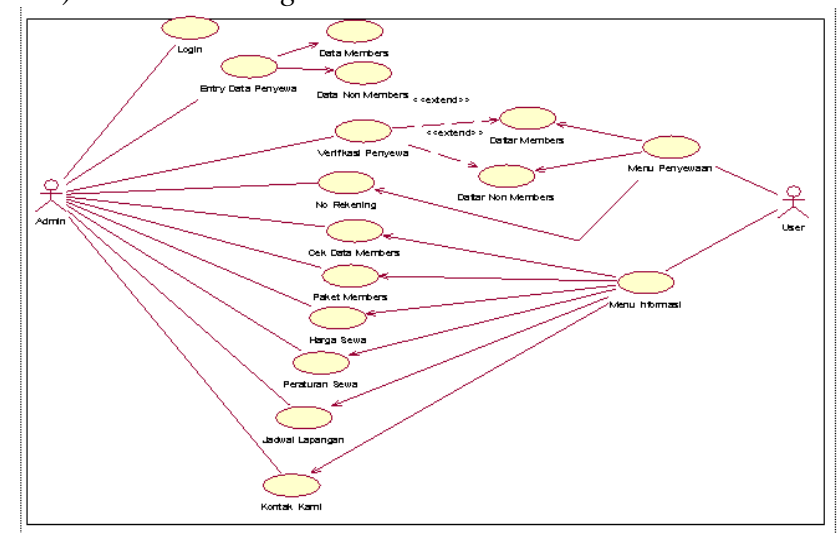

Gambar 1. Use Case Diagram
Diagram use case digunakan untuk memperlihatkan hubungan-hubungan yang terjadi antara aktor-aktor dengan use case-use case yang ada dalam sistem penyewaan lapangan futsal yang baru, sehingga calon penguna sistem/perangkat lunak mendapatkan pemahaman tentang sistem yang akan dikembangkan.

\section{2) Diagram Activity Admin}

Diagram aktifitas (activity diagram) merupakan diagram yang digunakan untuk menampilkan beberapa aktivitas yang dilakukan oleh Admin dan penyewa.

\section{3) Desain Tabel}

- Tabel admin digunakan untuk menyimpan data-data admin, disimpan dengan nama "admin" dan mempunyai atribut-atribut id_user, username dan password.

- Tabel member digunakan untuk menyimpan datadata member, disimpan dengan nama "member" dan mempunyai atribut-atribut id_member, no_identitas, nama_member, no_telp, kd_paket, hari_member, jam_member, tot_bayar.

- Tabel non member digunakan untuk menyimpan data-data non member, disimpan dengan nama "nonmember" dan mempunyai atribut-atribut id_non, no_identitas, nama_non, no_telp, tgl_non, jam_non, no_telp, tgl_non, jam_non, bnyak_jam, tot_bayar.

- Tabel harga digunakan untuk menyimpan data-data harga, disimpan dengan nama "harga" dan mempunyai atribut-atribut id_harga, hari,jam, harga.

- Tabel kepangkatan digunakan untuk menyimpan data-data paket, disimpan dengan nama "paket" dan mempunyai atribut-atribut kd_paket, jam_paket, nama_paket, banyak_jam, harga_paket.

- Tabel info digunakan untuk menyimpan data-data info, disimpan dengan nama "info" dan mempunyai atribut-atribut kd_info, judul_info, info

\section{4) Rancangan Antar Muka}

- Desain menu login admin merupakan menu login bagi admin sebelum mengakses menu utama admin.

- Menu utama admin adalah menu aksi pilihan admin yang tampil setelah admin melakukan login sebelumnya.

- Menu entry penyewa digunakan untuk mendata para penyewa lapangan futsal, baik sebagai member / non members.

- Menu verifikasi penyewa digunakan admin untuk menerima maupun menolak penyewa yang telah mendaftar secara online.

- Menu cek data members digunakan untuk melihat data members yang telah terdaftar.

- Menu paket members berisi info harga paket bagi members.

- Menu harga sewa berisi informasi harga sewa lapangan pada DoR Futsal. 
- Menu peraturan sewa berisi peraturan sewa pada DoR Futsal.

- Menu jadwal lapangan berfungsi sebagai jadwal penyewaan lapangan pada DoR Futsal.

- Menu kontak kami berisi informasi alamat DoR Futsal serta nomor telepon yang dapat dihubungi.

- Menu utama user adalah menu yang pertama kali dibuka oleh penyewa.

- Menu informasi berisi mengenai segala sesuatu informasi tentang penyewaan lapangan pada DoR Futsal.

- Menu pemesanan berisi menu pilihan bagi penyewa untuk melakukan pemesanan lapangan, baik sebagai members maupun non members.

- Menu pemesanan members digunakan penyewa lapangan yang ingin mendaftar sebagai members.

- Menu Konfirmasi. Pada menu ini terdapat tampilan data yang telah didaftarkan oleh members, total biaya yang harus dibayar dan juga terdapat tombol pilihan yaitu lanjut.

- Pada menu informasi pembayaran ini terdapat informasi mengenai id pemesanan user serta tata cara pembayaran serta konfirmasi pembayaran yang harus dilakukan, juga ada tombol back.

- Pada menu pemesanan non members ini terdapat form input user untuk daftar pesan non members, serta tombol kirim.

- Pada menu konfirmasi pemesanan non members ini terdapat tampilan data yang telah didaftarkan oleh non members, total biaya yang harus dibayar dan juga terdapat tombol pilihan yaitu lanjut.

- Pada menu informasi pembayaran non members ini terdapat informasi mengenai id pemesanan user serta tata cara pembayaran serta konfirmasi pembayaran yang harus dilakukan, juga ada tombol back.

- Pada menu informasi No rekening DoR futsal ini terdapat informasi mengenai no rekening DoR Futsal, juga ada tombol back.

\section{HASIL DAN PEMBAHASAN}

Berdasarkan hasil penelitian yang dilakukan pada DoR Futsal Baturaja, hasil akhir dari semua kegiatan dan tahapantahapan pengembangan sistem yang telah dilakukan merupakan penerapan dari rancangan-rancangan yang telah diuraikan pada langkah sebelumnya yang terdiri dari desain file, desain input, desain output. Adapun hasil dari penelitian ini berupa Sistem Penyewaan Lapangan Futsal Berbasis Mobile Android. Sistem ini dibuat dengan menggunakan bahasa pemrograman PHP.

Adapun langkah-langkah penggunaan dari sistem ini dapat dijelasakan sebagai berikut.

1. Halaman index adalah halaman yang pertama kali tampil ketika sistem dijalankan. Pada halaman ini menampilkan menu login admin. Admin harus memasukkan username dan password untuk bisa masuk ke sistem ini, jika username dan password tidak cocok/sesuai maka akan ditolak oleh sistem. Di bawah ini adalah tampilan halaman index.

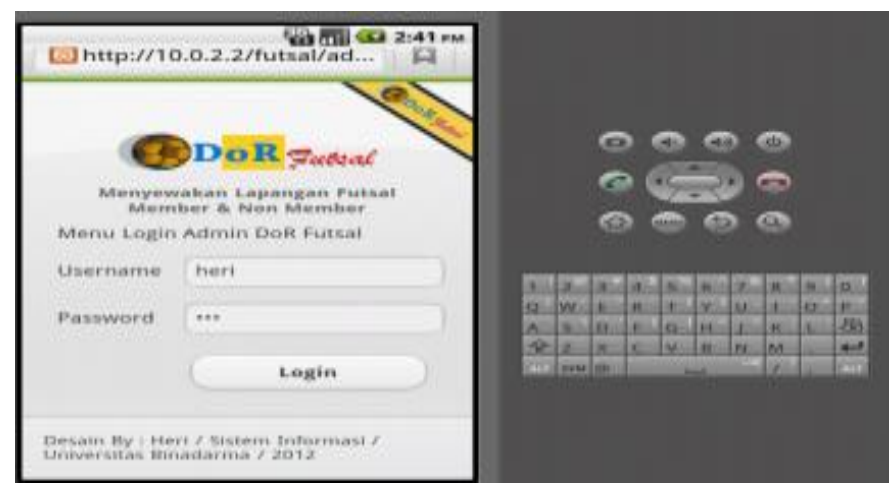

Gambar 2. Halaman index

2. Menu utama admin menampilkan menu pilihan bagi admin untuk melakukan suatu proses yang dipilih. Dimana admin bisa memilih entry penyewa, verifikasi penyewa, cek data members dan lainnya. Di bawah ini adalah tampilan halaman menu utama admin.

Welcome. DoR Futsal

Mienu Utama Admin

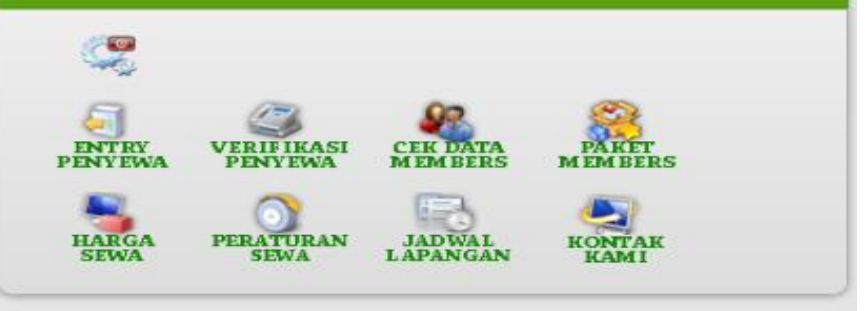

Gambar 3. Menu Utama Admin

3. Halaman menu entry penyewa berfungsi untuk menginput data penyewa yang memesan, baik berstatus members maupun non members.

\section{Welcome. DoR Futsal}

\section{Entry Penyewa}

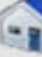

"Members

"Non Members

\section{Gambar 4. Menu Entry}

4. Halaman Menu Verifikasi Penyewa digunakan untuk memverifikasi bagi penyewa yang telah mendaftar baik members maupun non members, juga menampilkan info 
no rekening DoR Futsal untuk proses pembayaran via rekening.

5. Halaman cek data members, digunakan untuk mengecek data member yang telah terdaftar atau diverifikasi sebelumnya.

6. Berikut ini adalah halaman menu paket members admin yang bisa dipilih oleh member dalam proses penyewaan lapangan futsal. Menu ini berisi data jam, Kode paket, nama paket, banyaknya jam dan harga tiap-tiap paket members.

\begin{tabular}{|c|c|c|c|c|c|}
\hline \multicolumn{6}{|c|}{ Harga Paket } \\
\hline \multicolumn{6}{|l|}{$\theta \mathrm{\theta}$} \\
\hline Jam & $\begin{array}{l}\text { Kode } \\
\text { Paket }\end{array}$ & $\begin{array}{l}\text { Nama } \\
\text { Paket }\end{array}$ & $\begin{array}{c}\text { Banyaknya } \\
\text { Jamn }\end{array}$ & Harga & Aksi \\
\hline $08.00-14.00$ & A1 & Pagi10 & 10 & 900000 & $\frac{\text { Edit }}{\text { Del }}$ \\
\hline $08.00-14.00$ & A2 & Pagi 5 & 5 & 450000 & $\frac{\text { Edit }}{\text { Del }}$ \\
\hline $15.00-17.00$ & B1 & Sore 10 & 10 & 1200000 & $\frac{\text { Edit }}{\text { Del }}$ \\
\hline 15.00-17.00 & B2 & Sore 5 & 5 & 60000 & $\frac{\text { Edit }}{\underline{\text { Del }}}$ \\
\hline $\mid \begin{array}{l}19.00-23.00 \\
\end{array}$ & C1 & Malam 10 & 10 & 1500000 & $\frac{\text { Edit }}{\underline{\text { Del }}}$ \\
\hline $19.00-23.00$ & $\mathrm{C} 2$ & Malam 5 & 5 & 750000 & $\frac{\text { Edit }}{\text { Del }}$ \\
\hline
\end{tabular}

(Back)

Gambar 5. Tampilan Harga Paket

7. Halaman Menu Harga Sewa

Berikut ini adalah halaman menu harga sewa lapangan yang berisi informasi harga sewa pada DoR Futsal dengan informasi hari, jam dan harga sewa.

\begin{tabular}{|c|c|c|c|}
\hline \multicolumn{4}{|c|}{ Harga Sewa Lapangan } \\
\hline \multicolumn{4}{|l|}{$\because \square$} \\
\hline Hari & Jam & Harga & Aksi \\
\hline Senin-Jum'at & $08.00-14.00$ & 90.000 & Edit Del \\
\hline Senin-Jum'at & $15.00-17.00$ & 120.000 & Edit Del \\
\hline Senin-Jum'at & $19.00-23.00$ & 150.000 & Edit Del \\
\hline Sabtu-Minggu & $08.00-14.00$ & 100.000 & Edit Del \\
\hline Sabtu-Minggu & $15.00-17.00$ & 130.000 & Edit Del \\
\hline Sabtu-Minggu & $19.00-23.00$ & 160.000 & Edit Del \\
\hline (Back) & & & \\
\hline
\end{tabular}

\section{Gambar 6. Tampilan Harga Sewa}

8. Halaman Menu Peraturan Sewa

Berikut ini adalah halaman menu peraturan sewa pada DoR Futsal. Dimana menu ini berisi tata cara penggunaan sistem serta peraturan ini harus dipatuhi oleh setiap member yang akan melakukan proses penyewaan lapangan.

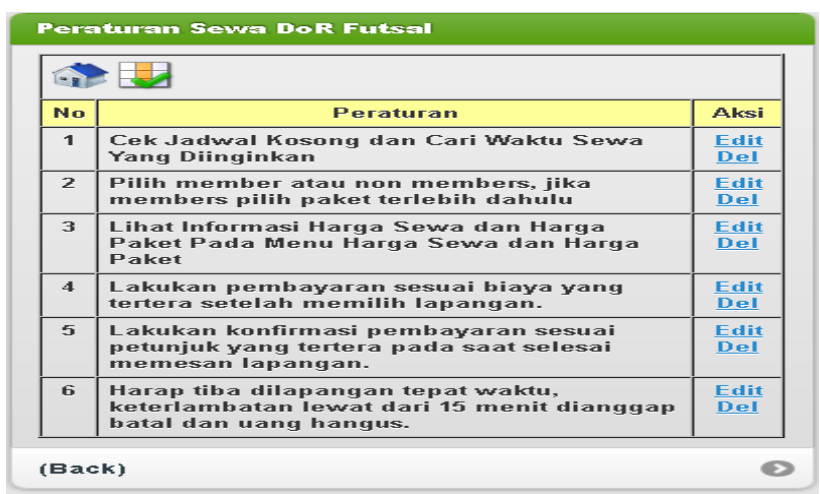

Gambar 7. Tampilan Peraturan Sewa

9. Berikut adalah menu jadwal lapangan, berisi jadwal penyewaan lapangan futsal yang suda terpakai oleh member penyewa DoR Futsal.

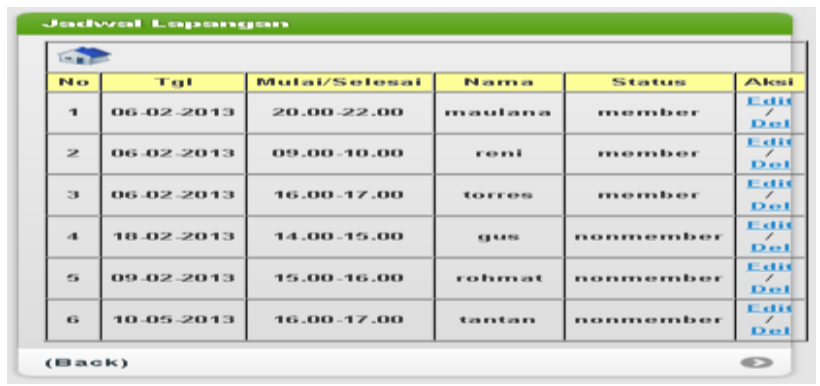

Gambar 8. Tampilan Jadwal Lapangan

10. Halaman menu kontak kami, yang berisi alamat dan nomor telepon dari DoR Futsal.

11. Halaman menu utama user, terdiri dari informasi, pemesanan dan exit. Di bawah ini adalah tampilan menu utama user. 


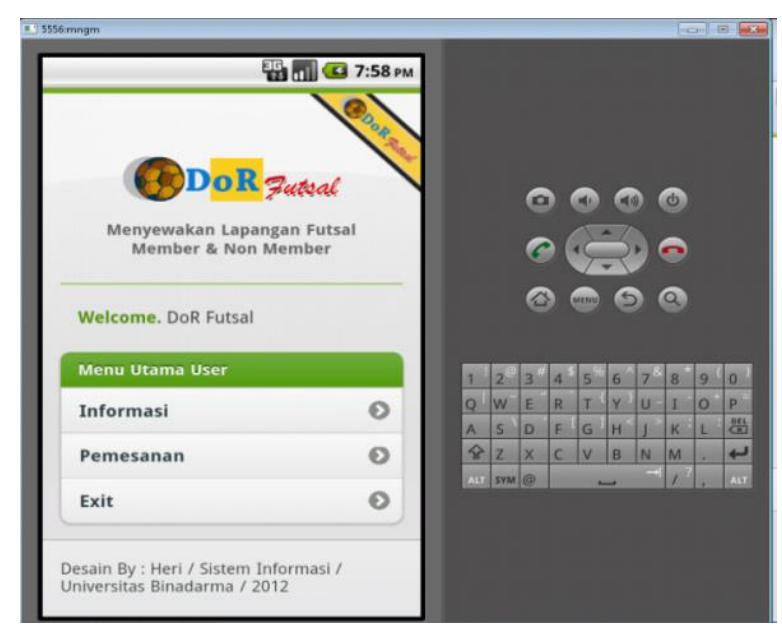

Gambar 9. Tampilan Menu Utama User

12. Halaman menu informasi. Berikut adalah halaman menu informasi bagi penyewa.

\begin{tabular}{|c|c|}
\hline \multicolumn{2}{|c|}{ Menu Informasi DoR Futsal } \\
\hline Peraturan Sewa & 8 \\
\hline Jadwal & (2) \\
\hline Data Members & (2) \\
\hline Harga Sewa & $\boldsymbol{2}$ \\
\hline Harga Paket & 8 \\
\hline Kontak Kami & $\boldsymbol{2}$ \\
\hline Back & 2 \\
\hline
\end{tabular}

Gambar 10. Tampilan Menu Informasi

13. Halaman menu pemesanan, berikut adalah halaman menu pemesanan bagi penyewa, baik pemesanan members maupun non members.

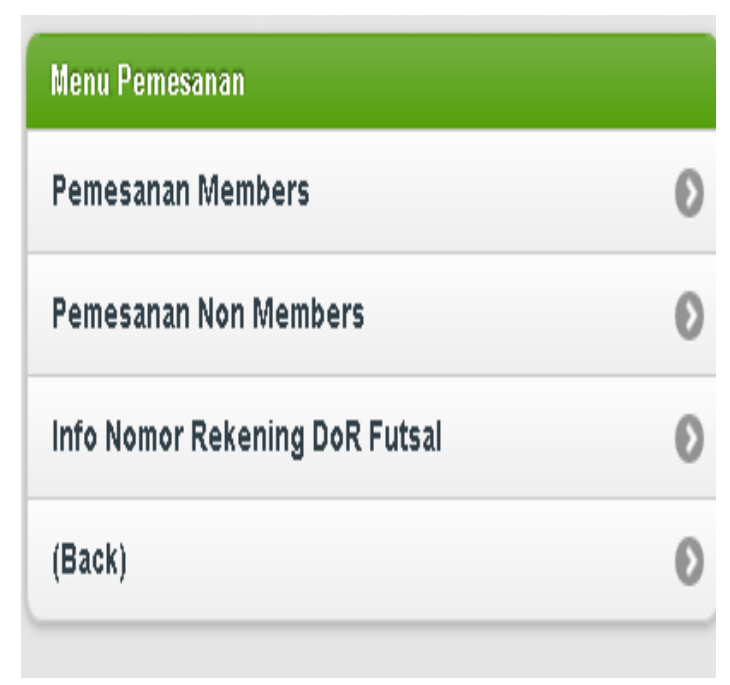

Gambar 11. Menu Pemesanan

Adapun menu-menu yang ada pada halaman pemesanan terdiri dari : halaman menu pemesanan members pada DoR Futsal. Jika telah selesai mengisi data pemesanan maka akan tampil halaman konfirmasi pemesanan members yang telah diisi sebelumnya.

Setelah melakukan konfirmasi, maka penyewa akan mendapatkan informasi pembayaran yang berisi ID pemesanan, total biaya yang harus dibayar dan nomor rekening yang dituju. Di bawah ini adalah tampilan informasi pembayaran.

\section{Informasi Pembayaran}

Anda telah melakukan transaksi pemesanan dengan № ID : 84 silahkan transfer uang sebesar 1.200.000, ke Rekening Kami Bank BNI Atas nama Febri Haryono dengan Nomor Rekening berikut : 0112214XXXX Setelah melakukan transfer, konfirmasi ke nomor berikut 085643196252 dengan menyebutkan id pemesanan anda. Anda memiliki waktu 1 hari untuk melakukan pembayaran, jika dalam 1 hari belum melakukan pembayaran maka pemesanan lapangan akan otomatis dibatalkan, terimakasih telah menggunakan layanan pemesanan kami (DoR Futsal).

(Back)

Gambar 12. Informasi Pembayaran Members

14. Halaman Menu Pemesanan Non Members

Halaman menu pemesanan non members pada DoR Futsal terdiri dari :

Halaman Menu Konfirmasi Pemesanan Non Members, Jika telah selesai mengisi data pemesanan maka akan tampil halaman konfirmasi pemesanan non members yang telah diisi sebelumnya. 
Halaman Menu Informasi Pembayaran Non Members. Setelah melakukan konfirmasi, maka penyewa akan mendapatkan informasi pembayaran yang berisi ID pemesanan, total biaya yang harus dibayar dan nomor rekening yang dituju.

Halaman Menu Informasi No Rekening DoR Futsal menu informasi no rekening, berisi no rekening DoR Futsal.

Tampilan Halaman Informasi Jadwal Telah Terisi, Namun apabila user memilih tanggal pemesanan dan jam yang telah dipilih oleh penyewa lain sebelumnya, atau telah terisi oleh penyewa lain yang telah terlebih dahulu diverifikasi. Maka akan tampil pesan peringatan seperti gambar dibawah ini.

\section{Konifirmasi Pemesanan Mlembers}

\section{Jadwal yang di pilih sudah terisi, Silahkan pilih jadwal lain.}

\section{Back}

\section{Gambar 13. Informasi Jadwal Terisi}

\section{Testing}

Merupakan teknik yang melengkapi untuk memeriksa cacat yang nampak dalam perangkat lunak. Namun penelitian tentang sistem penyewaan lapangan futsal ini hanya dilakukan sampai tahap code. Pengujian yang dilakukan hanyalah pengujian sederhana mengenai hasil input dan output dari sistem yang diharapkan. Dari hasil pengujian hasil yang dicapai telah sesuai dengan hasil yang diharapkan.

\section{KESIMPULAN}

Berdasarkan penelitian yang telah dilakukan dan telah diuraikan, maka dapat disimpulkan beberapa hal sebagai berikut :

- Dengan adanya sistem penyewaan lapangan futsal ini, penyewa tidak perlu lagi menelpon atau datang langsung ke tempat guna mendapatkan informasi dan menunggu bagian penyewaan mencari data informasi yang diminta penyewa. Hanya dengan membuka sistem dan memilih menu informasi, penyewa bisa mencari informasi yang diperlukan.

- Pendataan para penyewa lebih tepat karena telah dikelompokkan antara penyewa yang berstatus members dan non members. Jadwal penyewaan akan menampilkan para penyewa yang sudah mendaftar dan divierifikasi oleh admin.

- Seiring dengan kemajuan ilmu pengetahuan dan teknologi, maka tidak menutup kemungkinan sistem yang sudah ada ini nantinya akan dikembangkan lagi.

\section{DAFTAR PUSTAKA}

[1] Arifianto, Teguh. 2011. Membuat Inteface Aplikasi Android lebih keren dengan LWUIT. Yogyakarta. Andi.

[2] Fortina, Dewi Rossa. (2012). Pembuatan Aplikasi PemesananTiket Bus Pada PO Sinar Dempo Berbasis Android (studi kasus :kantor perwakilan PO Sinar Dempo Santura, Yogyakarta). Diakses 7 Oktober 2012, dari http://repository.amikom.ac.id/files/Naskah_Publikasi_08.12.3206.pdf

[3] Pressman, Roger S. 2002. Rekayasa Perangkat Lunak: Pendekatan Praktisi (Buku Satu). Yogyakarta : Andi

[4] Putra, M. Iqbal Merdeka Eka. (2012). Aplikasi Ponsel Berbasis Android Untuk Penjualan Pada Kios Eceran Q-Mono Flower. Diakses 7 Oktober 2012, http://repository.amikom.ac.id/files/Naskah_Publikasi\%2008.11.2057.pd f 